\title{
Honeywell
}

\section{K RESERVOIR: EB WELDER, CE69412 REQUALIFICATION}

Federal Manufacturing \& Technologies

J. H. Schell

Department ME6

KCP-613-8005

Distributed September 2005

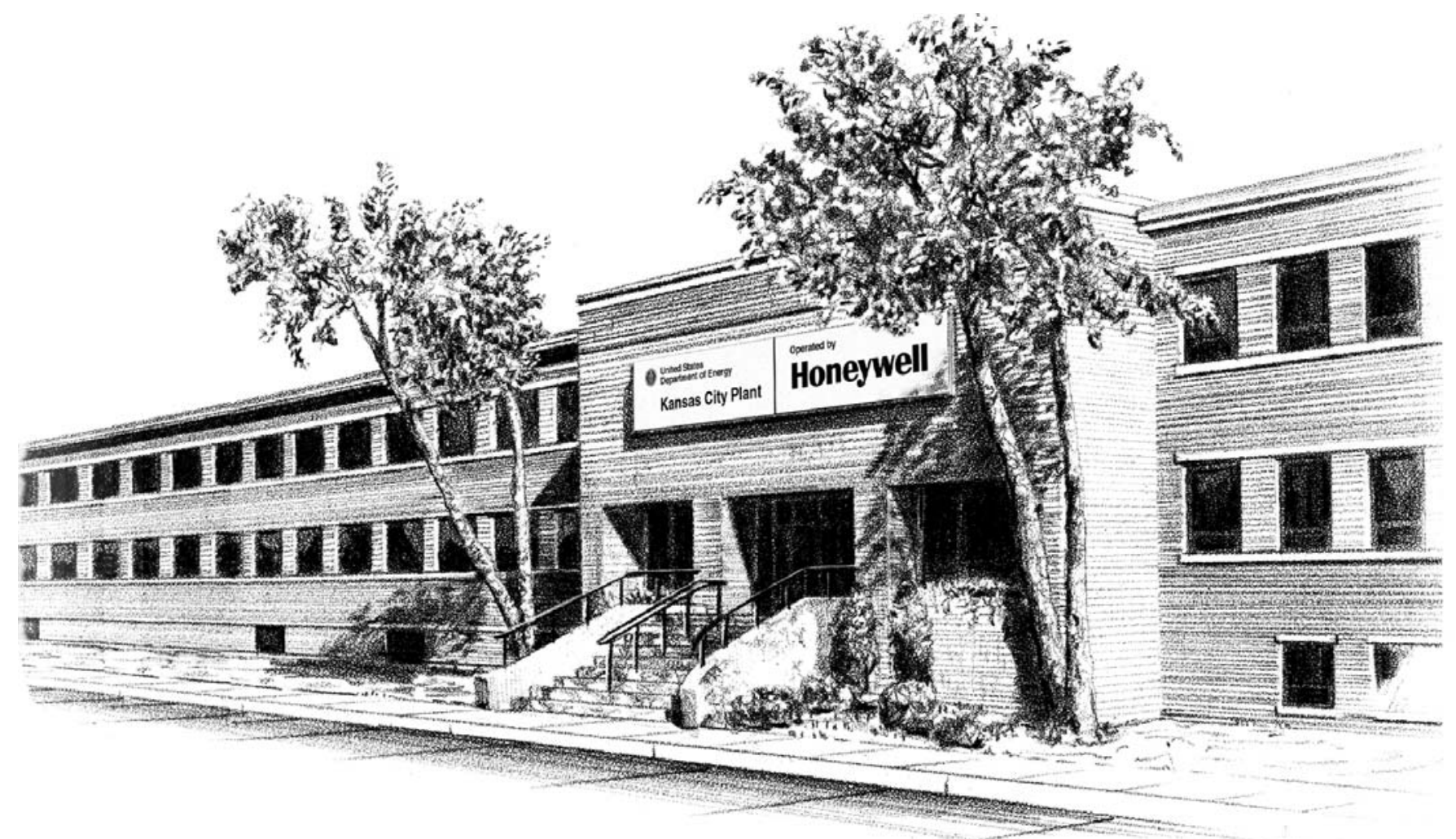

Prepared under prime contract DE-ACO4-01AL66850 for the United States Department of Energy 


\section{DISCLAIMER}

This report was prepared as an account of work sponsored by an agency of the United States Government. Neither the United States Government nor any agency thereof, nor any of their employees, makes any warranty, express or implied, or assumes any legal liability or responsibility for the accuracy, completeness, or usefulness of any information, apparatus, product, or process disclosed, or represents that its use would not infringe privately owned rights. Reference herein to any specific commercial product, process or service by trade names, trademark, manufacturer, or otherwise, does not necessarily constitute or imply its endorsement, recommendation or favoring by the United States Government or any agency thereof. The views and opinions of authors expressed herein do not necessarily state or reflect those of the United States Government or any agency thereof.

All data prepared, analyzed and presented has been developed in a specific context of work and was prepared for internal evaluation and use pursuant to that work authorized under the reference contract. Reference herein to any specific commercial product, process or service by trade name, trademark, manufacturer, or otherwise, does not necessarily constitute or imply its endorsement, recommendation or favoring by the United States Government, any agency thereof or Honeywell Federal Manufacturing \& Technologies, LLC.

Printed in the United States of America.

This report has been reproduced from the best available copy.

Available to DOE and DOE contractors from the Office of Scientific and Technical Information, P.O. Box 62, Oak Ridge, Tennessee 37831; prices available from (865) 576-8401, FTS 626-8401.

Available to the public from the National Technical Information Service, U.S. Department of Commerce, 5285 Port Royal, Rd., Springfield, Virginia 22161, (703) 487-4650.

A prime contractor with the United States Department of Energy under Contract Number DE-AC04-O1AL66850

\author{
Honeywell Federal Manufacturing \& Technologies \\ P.O. Box 419159 \\ Kansas City, Missouri, 64141-6159
}




\title{
Honeywell
}

\section{KCP-613-8005 \\ Distribution Category UC-42}

Approved for public release; distribution is unlimited.

\section{K RESERVOIR: EB WELDER, CE69412 REQUALIFICATION}

\author{
J. H. Schell \\ Department ME6
}

KCP-613-8005

Distributed September 2005

Project Team:

James Schell

Melvin Coss 



\section{Contents}

Section Page

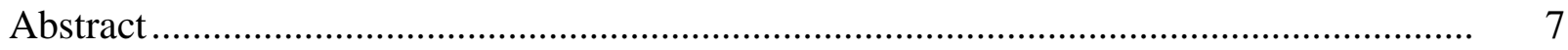

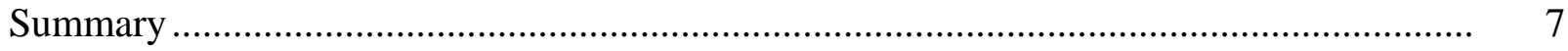

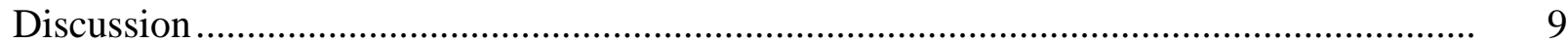

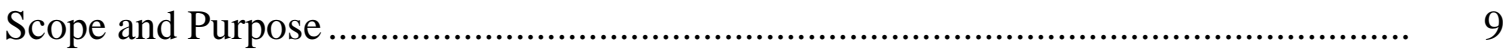

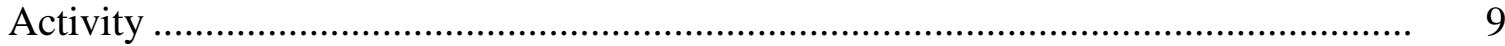

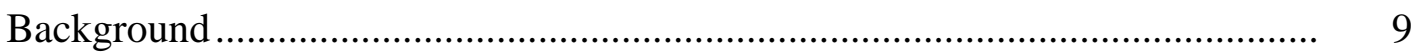

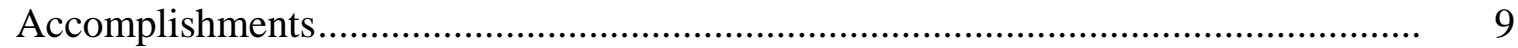

\section{Illustrations}

Figure Page

1 Figure 1 Nominal Cross Sections Results....................................................... 11

2 Figure 2 High Cross Sections Results............................................................ 12

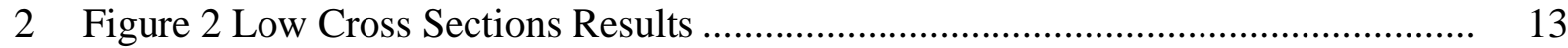

\section{Tables}

Number

Page

1 Table 1 WR Nominal Penetration and Cosmetic Weld Settings .............................. 10

2 Table 2a Run Order, Parameter Settings, and Penetration Results........................... 10

2 Table 2b Calibration Limit vs. Evaluation Limit Used for High and Low .................. 10 


\begin{abstract}
The EB Welder was qualified to produce the $1 \mathrm{~K}$ retainer weld in February 2001. Since that time, several parts were replaced and metallography results from a review indicated that the welder was not operating properly. After testing the EB Welder, it was requalified to produce the $1 \mathrm{~K}$ retainer weld.
\end{abstract}

\title{
Summary
}

The EB Welder was qualified to produce the 1K retainer weld in February 2001. Since that time, several parts were replaced and metallography results from a review indicated that the welder was not operating properly. In May of 2005, it was determined that 9 parts would be welded to demonstrate the welder capability. Metallography results from this evaluation verify that the welder is unchanged and capable of producing the1K Retainer to Stem Weld. 


\section{Discussion}

\section{Scope and Purpose}

The purpose of this document is to demonstrate the capability of the EB welder to make the $1 \mathrm{~K}$ Retainer to Stem Weld.

\section{Activity}

\section{Background}

The EB Welder was qualified to produce the $1 \mathrm{~K}$ retainer weld in February 2001. However, in early 2005, the high voltage transformers on the EB welder were replaced. After the replacement of the high voltage transformers, a review was conducted (in March of 2005) to requalify the EB welder to produce the $1 \mathrm{~K}$ Retainer to Stem Weld. Metallography results from that review indicated that the welder was not yet operating properly.

Following the March review, the roughing pump and focus power supply on the EB welder were replaced. In addition to these changes, Honeywell FM\&T proposed a change to the beam current setting.

In May of 2005, it was determined that an additional 9 parts at 3 high, 3 low, and 3 nominal would be welded to demonstrate the welder capability.

\section{Accomplishments}

Nine WR-quality 1K Retainer to Stem parts were welded in July 2005. The nominal parameters of this evaluation were unchanged from the WR parameters used to weld the $1 \mathrm{~K}$ Retainer to Stem since 2001. See Tables 1 and 2a for information about these parameters.

Metallography results from this evaluation verify that the welder is unchanged and capable of producing the $1 \mathrm{~K}$ Retainer to Stem Weld. The results of these evaluation welds are illustrated in Figures 1 through 3.

FM\&T opted not to pursue the proposed change to the beam current setting since it is not possible to adequately characterize due to the limited availability of war reserve (WR) parts. 
Table 1. WR Nominal Penetration and Cosmetic Weld Settings

\begin{tabular}{|c|c|c|}
\hline Parameter & $\begin{array}{c}\text { Nominal } \\
\text { Penatration } \\
\text { Value }\end{array}$ & $\begin{array}{c}\text { Nominal } \\
\text { Cosmetic } \\
\text { Value }\end{array}$ \\
\hline \hline $\begin{array}{c}\text { Accelerating } \\
\text { Voltage }\end{array}$ & 82 & 82 \\
\hline Beam Current & 16 & 12 \\
\hline Focus Current & 601 & 731 \\
\hline Spindle Speed & 22 & 22 \\
\hline
\end{tabular}

Table 2a. Run Order, Parameter Settings, and Penetration Results

\begin{tabular}{|c|c|c|c|c|c|c|c|c|}
\hline $\begin{array}{c}\text { Run Order } \\
\text { \& Date } \\
\text { Welded }\end{array}$ & S/N & $\begin{array}{c}\text { High } \\
\text { Voltage } \\
\mathrm{kV})\end{array}$ & $\begin{array}{c}\text { Beam } \\
\text { Current } \\
(\mathrm{mA})\end{array}$ & $\begin{array}{c}\text { Sharp } \\
\text { Focus } \\
(\mathrm{mA})\end{array}$ & $\begin{array}{c}\text { Focus from } \\
\text { Sharp (mA) }\end{array}$ & $\begin{array}{c}\text { Spindle } \\
\text { Speed } \\
(\mathrm{RPM})\end{array}$ & Penetration & $\begin{array}{c}\text { Width @ } \\
\text { O.070 inch } \\
\text { depth }\end{array}$ \\
\hline \hline $1,7-1-05$ & $14717^{\star \star}$ & 81 & 15.5 & 627 & $(-34) 593$ & 23 & 0.124 & 0.042 \\
\hline $2,7-1-05$ & $14854^{\star \star}$ & 82 & 16 & 631 & $(-30) 601$ & 22 & 0.158 & 0.048 \\
\hline $3,7-1-05$ & $14985^{\star \star}$ & 83 & 16.5 & 635 & $(-26) 609$ & 21 & 0.189 & 0.045 \\
\hline $4,7-5-05$ & 14855 & 81 & 15.5 & 627 & $(-34) 593$ & 23 & 0.127 & 0.044 \\
\hline $5,7-5-05$ & 14096 & 81 & 15.5 & 627 & $(-34) 593$ & 23 & 0.119 & 0.038 \\
\hline $6,7-5-05$ & $13822^{\star}$ & 83 & 16.5 & 635 & $(-26) 609$ & 21 & 0.180 & 0.073 \\
\hline $7,7-5-05$ & 14773 & 83 & 16.5 & 635 & $(-26) 609$ & 21 & 0.190 & 0.046 \\
\hline $8,7-5-05$ & 14991 & 82 & 16 & 631 & $(-30) 601$ & 22 & 0.157 & 0.046 \\
\hline $9,7-5-05$ & 14989 & 82 & 16 & 631 & $(-30) 601$ & 22 & 0.150 & 0.044 \\
\hline
\end{tabular}

Cosmetic Pass Parameters for all Nine Welds

$\begin{array}{llllll}\text { ALL } & 82 & 12 & 631 & +(100) 731 & 22\end{array}$

* Grove on O.D. surface prior to welding.

**Wire Brushed prior to welding

Note: See Table $2 b$ for the calibration and evaluation limits used.

Table 2b. Calibration Limit vs. Evaluation Limit Used for High and Low

\begin{tabular}{|c|c|c|}
\hline Parameter & $\begin{array}{c}\text { Calibration } \\
\text { Limit }\end{array}$ & $\begin{array}{c}\text { Evaluation } \\
\text { Limit }\end{array}$ \\
\hline \hline $\begin{array}{c}\text { Accelerating } \\
\text { Voltage }\end{array}$ & $+/-0.5 \mathrm{kV}$ & $+/-1.0 \mathrm{kV}$ \\
\hline Beam Current & $\begin{array}{c}+/-2 \% \text { of } \\
\text { reading }\end{array}$ & $+/-0.5 \mathrm{~mA}$ \\
\hline Focus Current & $+/-2.0 \mathrm{~mA}$ & $+/-4.0 \mathrm{~mA}$ \\
\hline Spindle Speed & $\begin{array}{c}+/-0.05 \% \text { of } \\
\text { reading }\end{array}$ & $+/-1.0 \mathrm{RPM}$ \\
\hline
\end{tabular}




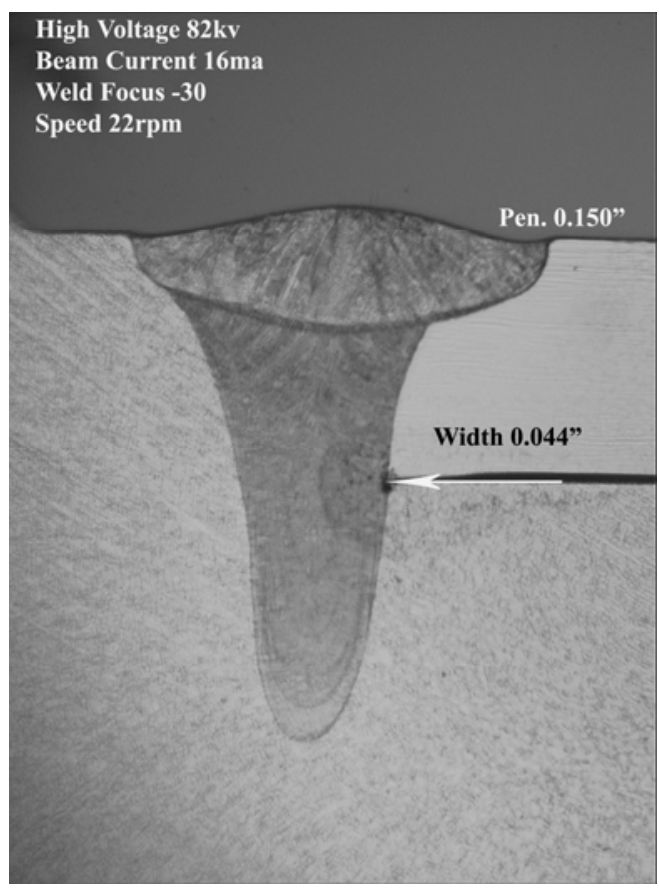

\section{High Voltage 82kv \\ Beam Current 16ma \\ Weld Focus - $\mathbf{3 0}$}

Speed 22rpm

Profiles of the Nominal penetration pass welds. The parameters are: Voltage: $82 \mathrm{kV}$, Beam Current: $16 \mathrm{~mA}$, Sharp Focus: -30mA, Spindle Speed: 22 RPM, Penetration 0.150 and 0.157 inches.

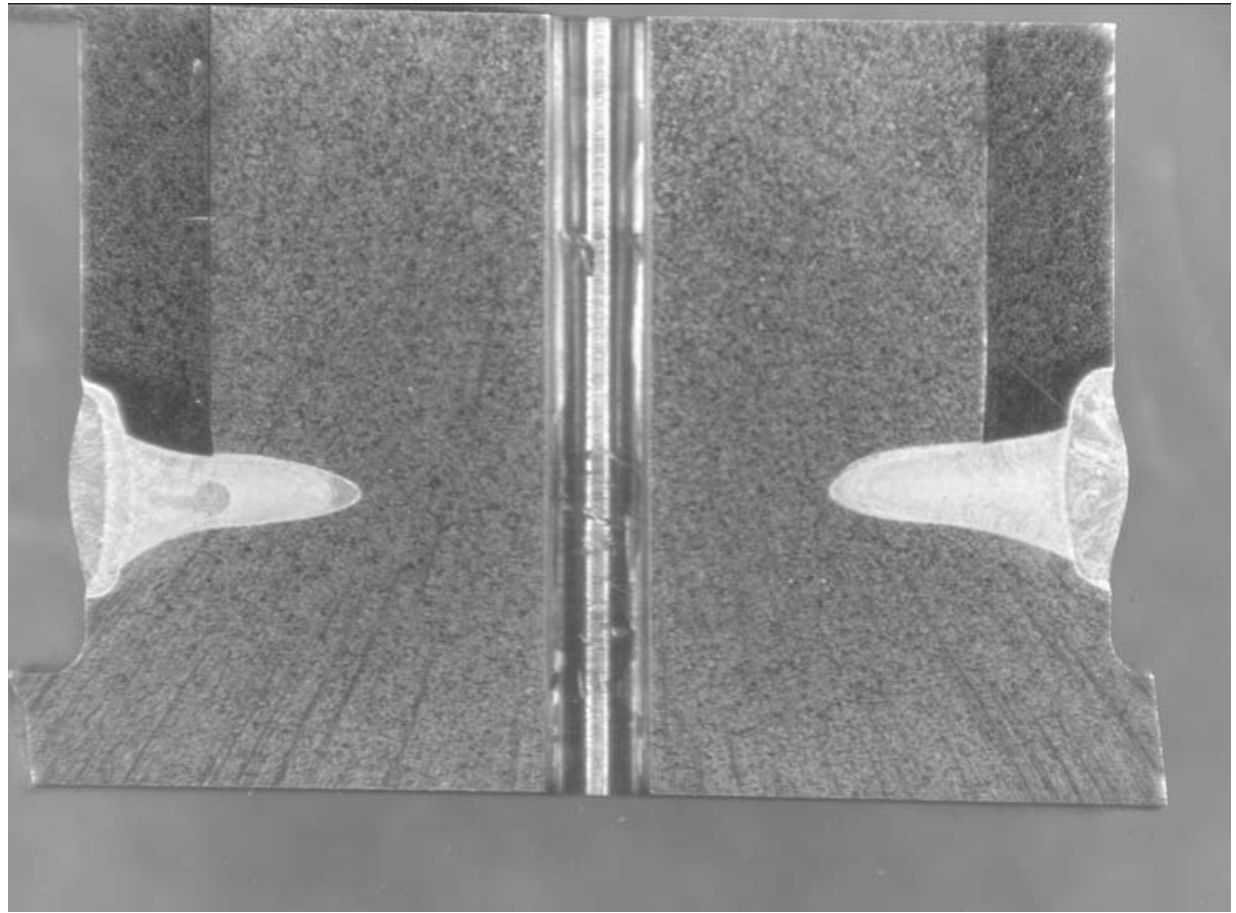

Overall nominal penetration profile

\section{Figure 1. Nominal Cross Sections Results}



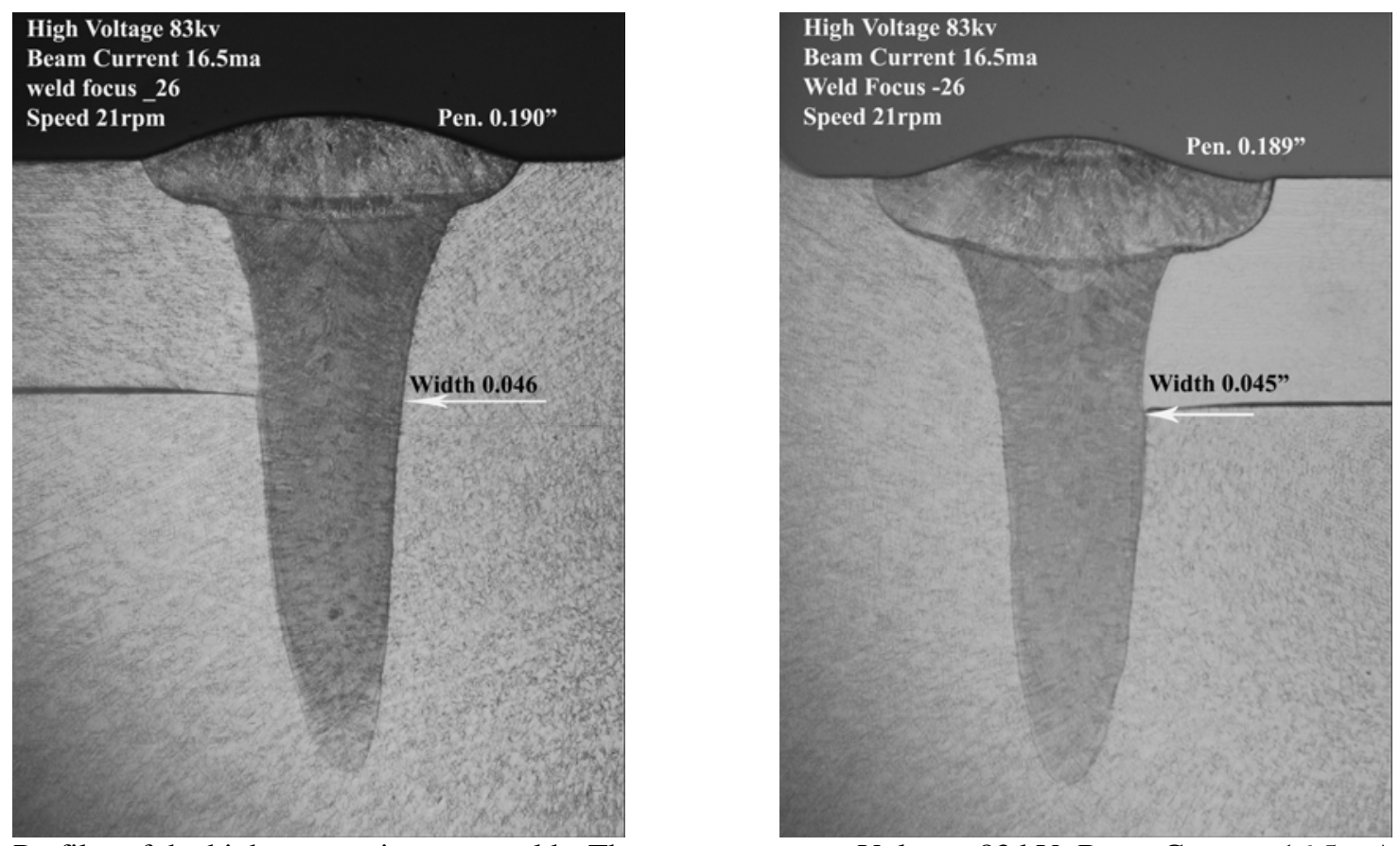

Profiles of the high penetration pass welds. The parameters are: Voltage: $83 \mathrm{kV}$, Beam Current: $16.5 \mathrm{~mA}$, Sharp Focus: -26 mA, Spindle Speed: 21 RPM, Penetration 0.190 and 0.189 inches.

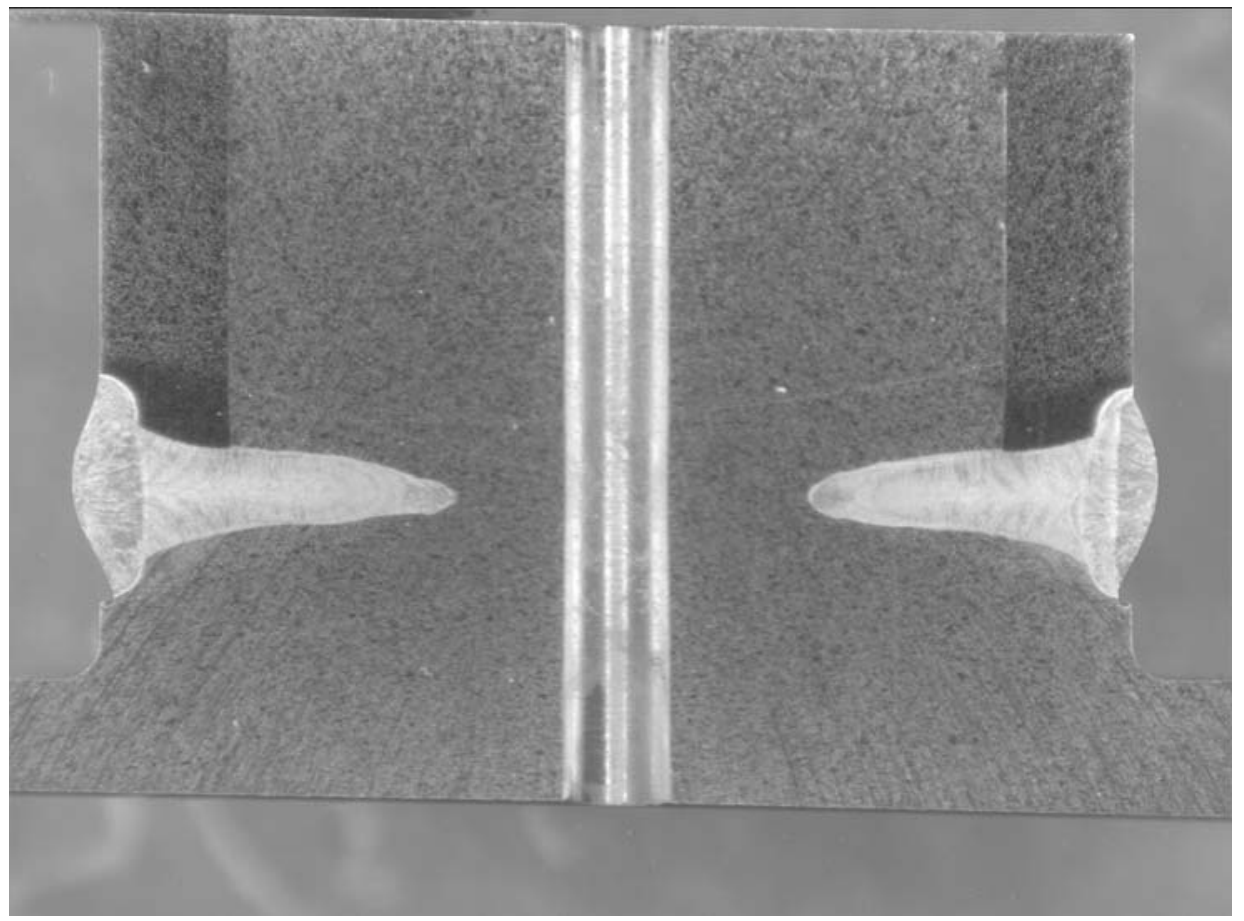

Overall high penetration profile

\section{Figure 2. High Cross Sections Results}



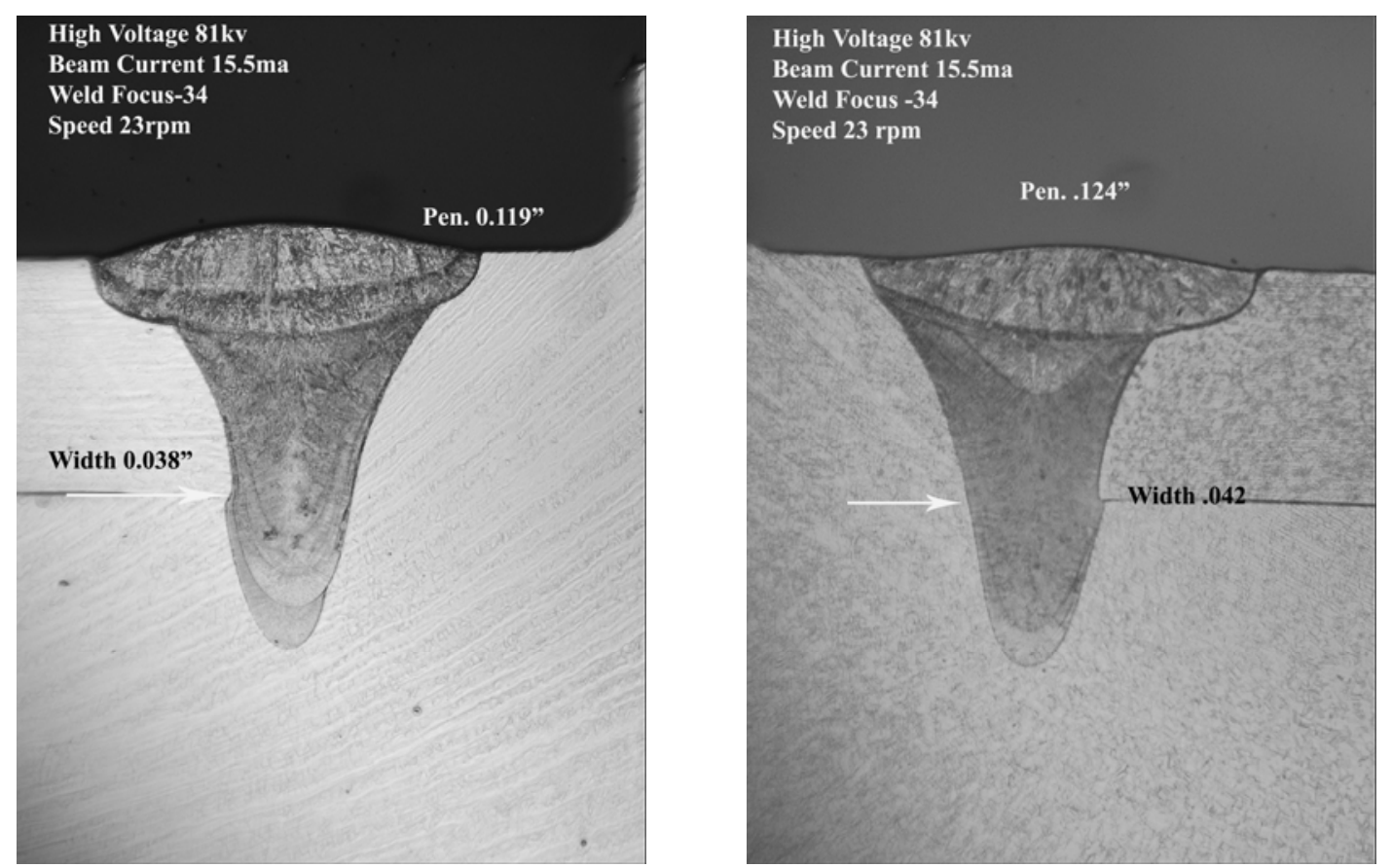

Profiles of the Low penetration pass welds. The parameters are: Voltage: $81 \mathrm{kV}$, Beam Current: 15.5 mA, Sharp Focus: -34 mA, Spindle Speed: 23 RPM, Penetration 0.119 and 0.124 inches.

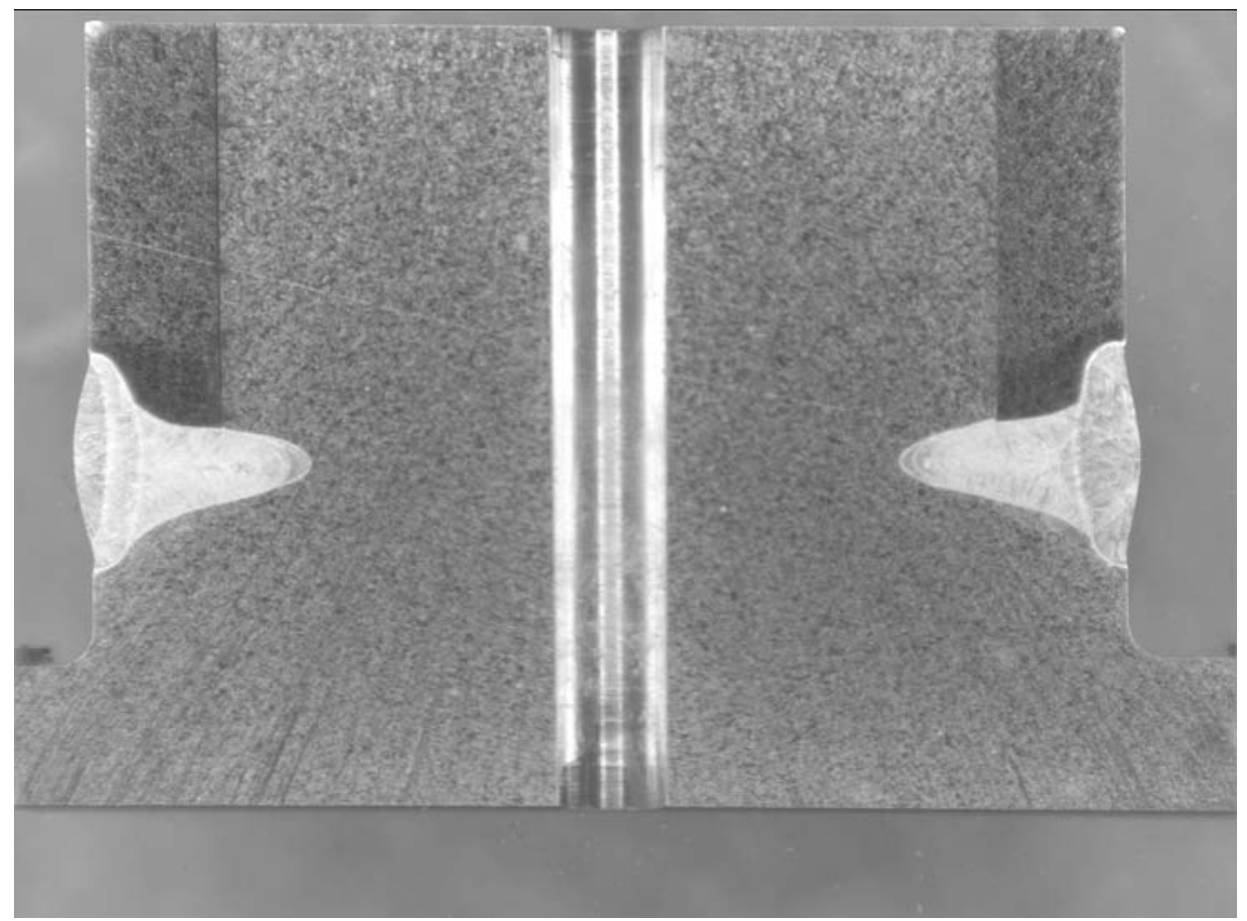

Overall low penetration profile

\section{Figure 3. Low Cross Sections Results}

